\title{
海事分野における安全目標の 国際的取り決め
}

田村兼吉

\section{1.はじめに}

海事分野における安全目標は、船舶関連と 海洋開発関連とを分けて考える必要がある。前 者は、国際航路を航行することから、国連の 下部機関であるIMO（International Maritime Organization：国際海事機関）が世界共通の安 全基準を定めている。一方、後者は、開発権を 与える国毎に独自の安全基準を定めることとなっ ているが、現在ではオイルメジャー等の後押し で、HSE (Health, Safety and Environmental Management System) がグローバルスタンダー ドとなっている。本稿では、その両者について 解説する。

\section{2. 船舶に関する安全目標の 取り決め}

最初の国際的安全規則であるSOLAS条約 （Safety Of Life At Sea）制定のきっかけが1912 年のタイタニック号事故であるように、従来 は、海難事故が起こり、その再発防止のために 規則を作り、さらにそれを改正してきた。例 えば、タイタニック号事故時には、水密区画 壁、救命設備、遭難通信について、1967年のト ニー・キャニオン号座礁・油流出事故では海洋 污染防止条約（MARPOL）の制定、1989年の エクソン・バルディス号座礁・油流出事故では、 タンカーのカーゴタンク区域の二重化を定めて
きた。しかし、1990年代から、海難事故を未 然に防ぐべきという議論が高まってきた結果、 リスク評価による規則作成方法FSA（Formal Safety Assessment）が、さらに目標を先に決 める GBS（Goal-based Standard）が制定されて きた。

\subsection{FSA}

FSA は、1993年 のIMO/MSC62（第62回 海 上安全委員会）において英国が提案し、その後 の議論および試験的な適用の積み重ねに基づい て最終的なガイドラインが承認された。FSAは 構造化され、客観性とトレーサビリティを有す る、包括的で合理的な安全性評価手法で、IMO における規則制定における意思決定のツールで ある。

FSAの手続き ${ }^{(1,2)}$ は図1に示すように、Step 1 ～Step 5の5段階に分かれている。

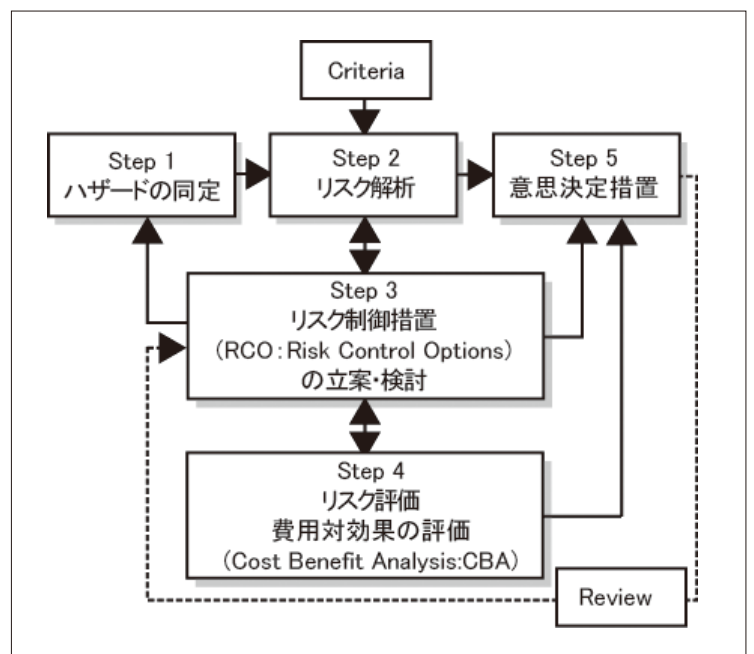

図 1 FSAの手続き 
Step 1では、事故に至る種々のハザード（危 険性）を同定する。同定には、HAZID会議や、 海難デー夕等の分析が組み合わされて用いら れる。Step 2では、事故確率、事故後の災害拡 大が生じる確率とその重大性を求めることに より、対象船舶の全体リスクを個々の事故シ ナリオのリスクの総和として求める。FSAで は事故の発生頻度と被害程度との積によってリ スクを定義しており、想定する被害は、人命 損失、環境影響、財産の喪失である。表 1 に示 すように、リスク許容基準としてALARP（As Low As Reasonably Practicable）領域の上下限 を定めている。なお、このリスク許容基準につ いては暫定的なものであり、見直しが行われて いる。Step 3では、リスク制御措置 RCO（Risk Control Options）を検討し、それらを導入した 場合のリスクの減少を推定する。Step 4では、 RCOを実現するためのコストを評価し、費用 対効果の評価を行い、RCOの優先順位付けを 行う。Step 5では、Step 4に基づき、導入すべ き $\mathrm{RCO}$ を提案する。

手順や検証の複雑さがあるものの、FSAを
用いた IMO提案は年々増加しており、電子海 図表示システム（ECDIS）の強制化、タンカー のイナートガスシステム（IGS）の強制化等が これを用いて規則化されている。また、安全に 関するFSAが成果を上げてきたことから、海 洋環境保全に関する新基準導入に際しても FSA の考え方を活用することが検討されている。

\subsection{GBS $^{(3)}$}

$\mathrm{IMO}$ における GBSの利用は、90年代後半か らエリカ号、プレスティッジ号と欧州沿岸で重 大海洋污染事故が続発したため、油タンカー、 ばら積み貨物船の船体構造基準を船級協会に任 せず、IMOが国際規則を定めるべきだという 意見がでてきたことによる。SOLAS条約では 「船体構造については，旗国が承認した船級協 会の規則に従うこと」と記されているのみで、 旗国が船体構造に関して評価していないことが 問題視されたわけである。2003年、旗国として 多くの船舶を登録していたバハマ及びギリシャ は、目標指向型の基準を制定すべき、との提案 をIMO理事会に行った。当初IMOのポリシー の問題と認識されて いた提案だが、その 後加盟国の合意を得 て体系を整えてきた。

IMOの GBSは、図 2 のような 5 階層の構造 を持っている。第1階 層：Tier I は達成す 
ベきゴールで、最初にこれを決定する。第 2 階 層：Tier II はゴール達成のために国あるいは船 級協会の船舶構造規則が持つべき基本的機能要 件であり、GBSの指針と言うべきものである。 第3階層：Tier III は各国政府及び船級協会の規 則である Tier IV がTier II の基本的機能要件を 具現していることを認証する方法を決定する。 第4階層：Tier IV は船舶に対する実際の規則で ある。第5階層：Tier V は実施細則であり、関 連規格等がこれにあたる。第 1 階層から第 3 階層 までをIMOで作成し、第4階層以下は船級協会 などが適宜規則策定を行うことを想定している。

タンカーとばら積み貨物船に関する GBSで は、目標は「北大西洋海域で耐用 25 年」とい うギリシャの主張が通り、定性的な解析と検討 に依って作成されている。しかしGBSの適用 は、船体構造だけ、タンカーやばら積み貨物船 だけに限られたものではない。安全のレベルを 定量的に把握し、目標とすることが引き続き求 められており、北欧、独、日本等の主張も採用

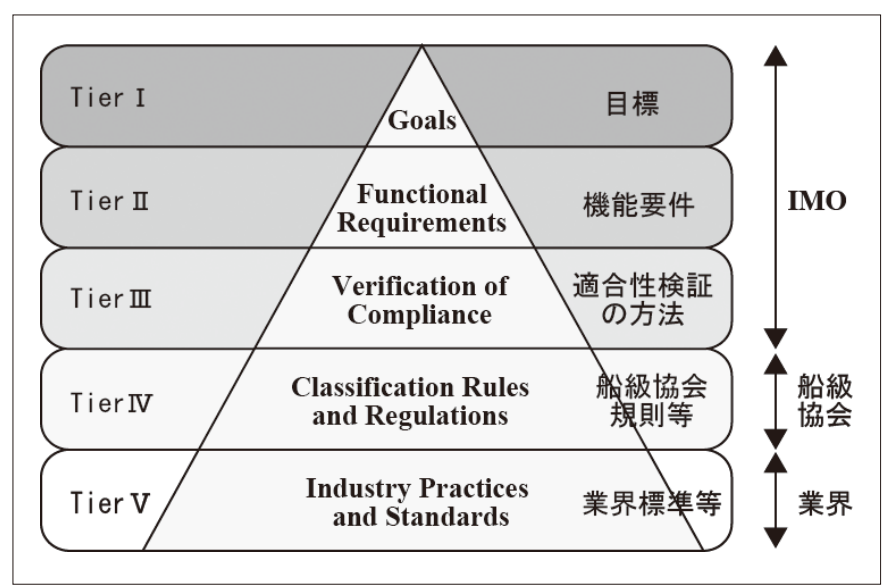

図2 GBSの階層構造

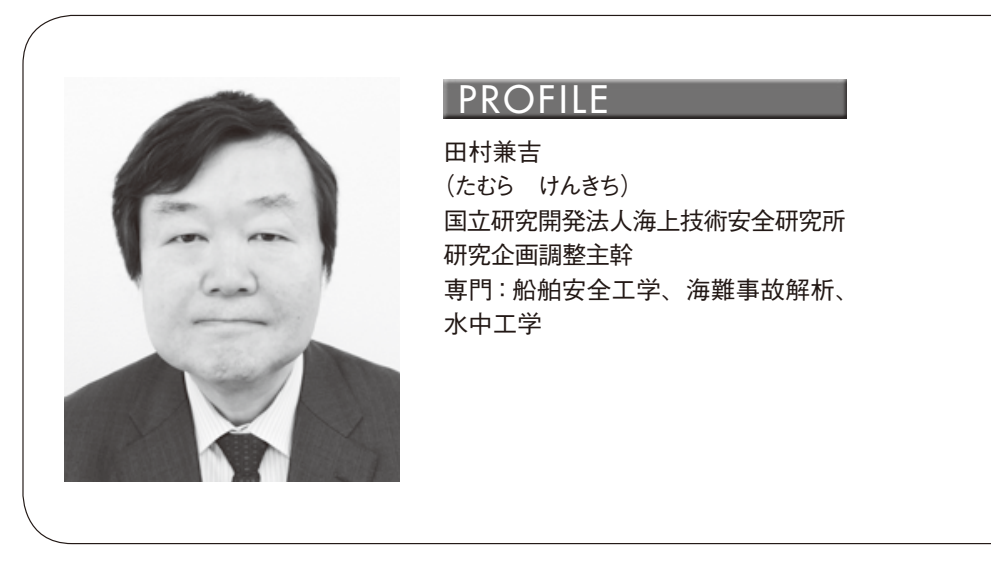

され、リスクコントロールを定量的に行うこと となった。

いくつかの国では、産業に扔ける目標安全レ ベルあるいは受け入れ可能なリスクレベルの設 定がすでに存在している。例えば後述する英国 の HSE では Maximum tolerable risk to workers が $10^{-3} 、$ Maximum tolerable risk to publicが $10^{-4}$ とされている。また、定量的なリスクアセ スメント及びその方法は、原子力、化学プラン 卜、石油精製施設、海洋構造物（海洋油田）等 ですでに存在しており、船舶に関しても、定量 的なリスクアセスメント方法及び受け入れ可能 なリスクレベルは確立可能と考えられている。

GBSは目標を達成するための船舶や海洋 構造物の設計に自由度があることから、 将来的にも有望な規則作成ツールと考え られている。

\section{3. 海洋開発に関する 安全目標の取り決め ${ }^{(4)}$}

海洋構造物は、各国が必要性に応じて 自国の海域で活動する海洋構造物の安全 
性に関する規則を作ってきたが、国家毎に新た な規則を作ることは難しく、先進的に海洋構造 物の規則を作ってきた国の規則が世界に急速に 普及して行くこととなる。英国で生まれたHSE が事実上デファクトスタンダードになったの は、以下の経緯である。

1988年、英国領海の石油生産プラットフォー ム Piper Alphaで 167名が死亡する大爆発事故 が起こった。事故調查委員会は、事故の主要原 因として(1)度重なる設計変更、(2)運用方法の問 題、(3)権限と責任が不明確、(4)緊急事態訓練の 軽視、を指摘し、106件もの勧告をおこなった。 この勧告を受けて、英国安全衛生庁（HSE）は 英国が管轄する海域で操業する海洋構造物での 重大事故・災害のリスクを低減させることを狙 いとするSafety Case 法を1992年に制定した。 英国の領海・大陸棚で操業する海洋構造物に対 して「客観的な安全性評価」「自律的な安全管 理体制」を要求し、安全衛生庁が書類審査を行 い、それを 3 年ごとに政府が更新Auditすると いうものである。オイルメジャーはこの Safety Case法を全面的かつ協力的に受け入れるとと もに、その後、世界中で海洋構造物を対象に HSEを広げるよう後押ししていく。

1994年、E\&P Forum（国際石油・天然ガス生 産者協会) は、オイルメジャーとしてのHSEマネ ジメントシステムのガイドライン Guideline for the development and application of Health, Safety and Environmental Management System ${ }^{(5)} を$ 発表した。このガイドラインは海洋構造物の
Operation（操業）を主たる対象として作成さ れている。考え方の骨子は「リスクアセスメン トを基にしたPDCAサイクル指向」「合理的か つ実行可能なリスク低減策は全て採用するとい う社会経済性価值観 (ALARP概念)」であり、 HSEマネジメントシステム確立の必要条件と して、品質マネジメントシステム、環境マネジ メントシステムと労㗢安全衛生マネジメントシ ステムの三つの確立をあげている。

その後、オイルメジャーはHSEマネジメン トシステムの適用対象を船舶・海洋構造物の建 造分野（新造・修繥）にまで拡大し、2003年 にOCIMF Health, Safety and Environment at New-Building and Repair Shipyard and during Factory Acceptance Testing ${ }^{(6)}$ を制定し、船舶 や海洋構造物の新造や修理・改造の商談開始の 条件として、造船所にHSEマネジメントシス テムが確立されていることを要求し始めた。単 に安全衛生の向上にツールというだけでなく、 受注競争に参戦するための必要条件としての意 味合いも付加されてきたため、世界の造船所が HSEを急速に導入していった。

2010年 4 月メキシコ湾の石油流出事故を契機 に、オイルメジャーはHSEにますます力点を 置いてきており、一般船主も HSE 導入への賛 同が増加している。またIACS（国際船級協会） でもHSE推進活動に沿って、造船所、協力会社、 舶用機器メーカ等における船級検查員と工場の 全作業員の安全衛生を追求する方針をアピール しており、海洋開発分野では、ますますHSE 
がデファクトスタンダードの地位を確立しつつ ある。

\section{4. おわりに}

海事分野の安全目標は、ALARPの概念を取 り入れた確率論的な取り扱いが主流となり、そ の対象も広がりつつある。なお、海洋開発関連 はもちろんのこと、船舶関連でも絶対的に数の 少ない客船やフェリーを除けば、対象とする人 命は一般の乗客ではなく乗員であることがメイ ンであることが他の交通機関と大きく異なる。

\section{参考文献}

(1) IMO Secretariat: Consolidated text of the Guidelines for Formal Safety Assessment (FSA) for use in the IMO rulemaking process (MSC/Circ. 1023-MEPC/Circ.392), MSC 83/INF.2 (2007).

（2）金湖富士夫、有馬俊朗：船舶海洋分野におけるリスク評 価の事例としてのFSA、海上技術安全研究所報告第8巻第 4 号 (2009).

(3) IMO: International Goal-Based Ship Construction Standards for Bulk Carriers and Oil Tankers, Focus on IMO (2015).

(4) HSEマネジメントシステム導入のためのガイドライン、日 本海事協会 (2015).

(5) Guidelines for the Development and Application of Health, Safety and Environmental Management Systems E \& P FORUM (1993).

(6) OCIMF Health, Safety and Environment at New -Building and Repair Shipyard and during Factory Acceptance Testing (2003). 